\title{
From struggling to survive to a life based on values and choices: first-person experiences of participating in a Norwegian Housing First project
}

\author{
Ellen Andvig* \\ Faculty of Health Sciences \\ Buskerud and Vestfold University College \\ Email: ellen.andvig@hbv.no \\ ${ }^{*}$ corresponding author \\ Jan Kåre Hummelvoll \\ Faculty of Health Sciences \\ Buskerud and Vestfold University College \\ Email: jankhum@online.no
}

\begin{abstract}
Introduction: Persons with concurrent substance-abuse and mental-health problems often lack permanent housing, and have a poorer quality of life and lower levels of functioning than persons who primarily have mental-health problems. A Housing First project (HF) began during the autumn of 2013 in a Norwegian city. The target group was persons who were struggling with substance-abuse and mental-health problems and who lacked housing. The HF model has a holistic health and social approach to help this group to establish themselves and to be able to remain in their own homes.
\end{abstract}

Aim: Little is known about how the HF model works in Norway. The aim of this study was to explore, describe, and interpret clients' experiences of partaking in this HF project.

Method: The qualitative research interview was used as the method for the generation of data. Twelve participants were interviewed, and a phenomenological hermeneutic method was used to analyse the data.

Results: The structured analysis revealed two themes, and the comprehensive understanding centred around these two interwoven themes: having an available professional companion and taking the lead in your own life. 
Discussion: This study shows that people with a dual diagnosis can begin to recover and obtain a better quality of life if they receive appropriate housing, support, and services of their choice on their own terms. The study confirms the importance of the participants' active participation, control, and choice in planning and formulating specific services. The results show that if a person wishes and dares to change his or her life, then decisive conditions are having one's own home, meeting professionals who inspire trust, and having one's personal preferences and needs recognized.

Keywords: Housing First Model, dual diagnosis, recovery, empowerment, person-centredness

\section{Introduction}

Persons with a dual diagnosis often lack permanent housing, and have poorer quality of life and lower levels of functioning than persons who primarily have mental-health problems (Norwegian Board of Health Supervision, 2000). Issues associated with dual diagnosis and homelessness are regarded as being difficult to address. These persons have been labelled 'hard to serve' by service providers (Padgett et al., 2006; Pearson et al., 2009), and they often fall through the cracks of services (Nooe \& Patterson, 2010). However, Norwegian health and social policy underscores that they have the right to receive the necessary and individually adjusted services in order to be able to live in their own home (Official Nowegian Reports 2011:15; Norwegian Directorate of Health, 2012). The White Paper, Se meg! (See Me!) (20112012), focuses on prevention and prompt measures for people with problems related to substance abuse. It is pointed out that the services must be provided promptly and coordinated better, and should be adapted more closely to the person who needs help. Focus should be placed on measures to improve cooperation. In the Guidelines of the Norwegian Directorate of Health for services for people with dual diagnosis (recommendation no. 37), it is pointed out that the person's own resources must be continually utilized in such a way that their quality of life is improved.

The Housing First project started during the autumn of 2013 in a Norwegian city. The target group was persons struggling with concurrent substanceabuse and mental-health problems and who lacked housing. However, 30 per cent of them had some kind of housing arrangement but were in danger of losing it. The project was based on the Housing First Model (the HF model) and had a proper HF ideology following the HF principles strictly. The housing of the participants was independent, scattered-sited (i.e., housing spread in usual living areas), and permanent. The participants had the same rights and level of security as anyone who rents housing in Norway. They were not expected to move out of the programme after a certain time. The project was planned to last for three years and was supposed to be continued as ordinary practice after the end of the project. The municipality, the Norwegian Housing Bank, and the Directorate of Health financed the project. It was not part of a national programme, but in recent years several municipalities in Norway have developed variations of the HF model (cf. Snertingdal, 2014). The project had five employees with interdisciplinary health and social professional education (mental-health nursing, psychology, social work, and one person with user- 
experience of mental-health problems, who was fully integrated as a member of the team). The team was anchored in the municipality and offered flexible floating support following an Intensive Case Management model. The team was going to follow up 30 participants. The support was based on the participants' needs and choices, for example, when a participant uttered some dream or an interest in having a job or education, they began to work towards this goal.

\section{The Housing First Model}

The HF model has a holistic health and social approach to help the participants of this group to establish themselves and to be able to remain in their own homes (Tsemberis, 2010). The HF model was developed in the USA. It is based on the idea that the person is to be allocated permanent housing at once. There should be no conditions attached to the housing regarding level of functioning, being drug-free, or having treatment. Instead, follow-up services are connected to the person, not the accommodation. According to the model, it is assumed that it is a fundamental right to have permanent accommodation, and that the person should have the freedom of choice regarding housing and help to get a place to live (Tsemberis, 2010). Further key principles are that the participants are to be treated with respect, compassion, and warmth. The staff members must have a commitment to work with the participants for as long as it is needed. The housing provided should be scattered-sited and the apartments independent. Housing and services are also to be separated. The services are to be provided according to the participants' perspective, and organized so as to allow them to define their own needs and aims. The services are not to be dependent on available capacity, and administrative procedures are not to take a long time. Other important principles are an orientation towards recovery and the reduction of harm (cf. Tsemberis, 2010).

With regard to the HF principles, most studies have examined experiences from the United States (e.g., the Pathways to Housing Project in New York) rather than in Europe. HF is regarded as an evidence-based programme in the US (National Registry of Evidence-Based Programs and Practices, 2010).

The HF model for people with a dual diagnosis has been developed as an alternative to the traditional 'treatment-first' approach. According to this approach, participants must first qualify in order to be allocated a place to live. In other words, before they are allocated housing they must undergo treatment to become rehabilitated and drug-free. Several studies have been carried out that have compared the advantages of participating in these two types of programme. These studies have shown that participants in HF programmes have a significantly lower rate of substance abuse, have fewer symptoms of mental disorder, and stay longer in HF programmes than participants in treatment-first programmes (Padgett et al., 2011; Tsemberis et al., 2012).

Several studies of HF in the US have demonstrated success with persons with severe mental illness (Gilmer et al., 2010; Gulcur et al., 2003; Tsemberis et al., 2004). Previous studies of HF programmes have demonstrated that within one or two years after entry into the programme a majority of participants experienced significant improvements in housing stability (Tsemberis et al., 2004; Stefancic \& Tsemberis, 2007; Gilmer et al., 2010). They also experienced mental-health functioning (Mares \& Rosenheck 2010), consumer 
choice (Tsemberis et al., 2004), quality of life (Gilmer et al., 2010; Patterson et al., 2013), and reduction in health-service use such as emergency and inpatient services (Gilmer et al., 2010).

A review of the literature by Kertesz et al. (2009) has reported that addiction severity was not always formally measured in HF studies, but was often lower than for homeless persons seeking addiction treatment. The authors criticized the published research on HF for providing less insight into how these programmes work for persons with severe and active substance abuse.

Atherton and McNaughton Nicholls (2008) have explored the applicability of HF in Europe. The authors conclude that the HF approach is not a simple philosophy that can be applied everywhere. They emphasize that adjustments to the programme are needed in order to meet the requirements of local needs. They also point out that it is difficult to draw any general conclusions regarding the results because projects based on the HF concept differ from one another in the range of problems associated with the client base, the ownership of the housing stock, the organization of services, and the number and skills of staff. These findings are also confirmed in a study of the implementation of Housing First in 12 municipalities in Norway (Snertingdal, 2014).

In the EU, Denmark, Finland, France, Ireland, and Sweden have placed HF at the centre of their national homelessness strategies (Pleace, 2011). A European study by Busch-Geertsema (2014) has reported that evaluations of five HF programmes in five different countries in Europe confirm high housingretention rates with this approach in four of the five projects. The study shows that the approach worked in different local contexts and with some variations of the original HF model once the core principles of the HF approach were followed (Busch-Geertsema, 2014).

\section{Recovery}

The HF model is based on a philosophy of recovery (Tsemberis, 2010; Tsemberis et al., 2012). This philosophy underscores the understanding that people with serious dual diagnosis can recover and that their quality of life can be improved. It is important to consider recovery from mental-health problems and substance abuse as simultaneous processes. Two separate treatment systems have existed for a long time. This has led to an incomplete understanding of the problem, and the result has been that persons with a dual diagnosis have fallen between two stools (Nooe \& Patterson, 2010).

Recovery is a deeply personal, unique process involving changes to one's values, feelings, aims, skills, and roles. It is about living one's life with hope, well-being, and the possibility of contributing despite the limitations that substance-abuse and mental-health problems have caused. Recovery involves new meaning and new aims in life, and the possibility to grow and develop (cf. Anthony, 1993).

Recovery as a personal process is thus concerned with what is involved in living with and overcoming mental-health and addiction problems. This definition has led to an improved understanding of the importance of everyday life for people with mental-health issues, and the importance of developing strategies for coping with psychological and social problems in daily life 
(Deegan, 1988; Davidson, 2003; Slade, 2009). Ness et al. (2014) have found that creating a meaningful everyday life, focusing on resources, being orientated towards the future, and re-establishing a social life and supportive relationships were important in the recovery process for people with a dual diagnosis.

We know little about how the HF model works in Norway. Additionally it was important to explore how this HF project was experienced and perceived in a first-person perspective. The aim was to explore, describe, and interpret participants' experiences with partaking in this HF project. The research question was: How do the participants describe their experiences with the HF project?

\section{Method}

Twelve of 23 clients were included in the study, three women and nine men (between 20 to 65 years of age). Most of them were in their twenties or thirties. They were struggling with addiction problems or mental-health problems, or both. Some of them had struggled with drug-dependence for many years. When attending the project all of them had problems with buying or renting a property and with keeping a dwelling over time. Several had periodically lived on the street. Many of them lived in temporary accommodation characterized by drug abuse, noise, and crime. Four of them were receiving workassessment allowance, two were receiving disability benefit, and two had temporary jobs.

All the informants were participating in the project when the interviews took place; nine had participated for six months and three for four months. The project staff asked the informants if they would participate in the study. The qualitative research interview was the method used to collect data. This method is suitable for detecting human experience related to different research questions (Kvale \& Brinkman, 2011). The aim was to collect descriptions of the clients' everyday life experiences. The interviews were carried out as open conversations with a theme-based interview guide, related to their experiences of participating in the project. The interviews lasted from 15 minutes (two participants) and from a half to one hour for the rest of them, and they took place in the spring of 2014. Ten interviews took place at the city library, and two interviews were carried out in the informants' homes. The interviews were recorded and transcribed verbatim. After the interviews were carried out, in order to check trustworthiness and communicative validity of the findings, six of the 'hard-to-reach' participants were interviewed about their experiences of participating in the project. They were paid 300 NOK (approximately 35 euros) as compensation for the inconvenience of coming to an interview. These six persons had participated in the project for one year and a half.

\section{Analysis of the data}

A phenomenological hermeneutic method (Lindseth \& Norberg, 2004) was used to analyse the data material - a method inspired by Ricoeur's philosophical ideas on interpretation (Ricoeur, 1976) - and it emphasizes the dialectic movement between understanding and explanation, and between the text as a whole and its parts. The task is to get at the meaning of the studied 
phenomena. The analysis was carried out in three stages: 1) naïve reading, 2) structured analysis, and 3) overall understanding. On the basis of the naïve reading, relevant units of meaning were identified. In the structured analysis, units of meaning were condensed into sub-themes. The amount of text was reduced, but the meaning in the expressions was retained. Sub-themes that had the same meaning were collected and abstracted into two themes: having an available professional companion and taking the lead in one's own life (cf. Table 1).

\section{Ethical considerations}

The Norwegian Social Science Data Services approved this study (project nr. 36241). The informants received both verbal and written information about the study from the project leaders. It was emphasized that they could withdraw from the project at any time and without giving a reason. A withdrawal would not have any consequences for them. Also, it was stressed that the data would be treated confidentially and the results would be presented anonymously.

\section{Results}

Through the naive reading, we found that the informants told that they had progressed from a hopeless situation to a new and better situation after they had begun in the project. This involved experiencing that they received support from the staff on their own terms, and that they could decide themselves about the help they received. The informants described the staff as helpers who were available when they needed them, and who gave them help when required. In particular, they valued the practical help and support they received for carrying out everyday tasks. They described the staff as considerate, committed, and easy to talk to. The staff related to the informants in a way that inspired confidence and acknowledgement. The informants compared their experiences of these members of staff who cared with the staff in NAV, the Norwegian Labour and Welfare Service, who did not care, who gave them the feeling of powerlessness, and who lacked an accommodating attitude and understanding. Participation in the project led to a feeling that life had become better, with more peace and security, which increased their motivation to bring about changes in their lives. The results of the interviews are shown in Table 1. The themes and sub-themes are first described and then given an overall interpretation.

\section{Having an available professional companion}

This theme is about the informants' descriptions of the availability of the staff in their everyday life and about staff who cared. One of them put it this way:

They can follow me and be with me. They are just pleased to be with me; they help me no matter what; they are with me all the time; I get help with exactly what I need. 
Table 1: Overview of the units of meaning, subthemes, themes, and overall understanding.

\begin{tabular}{|c|c|c|c|}
\hline $\begin{array}{l}\text { Unit of meaning } \\
\text { (empirical data) }\end{array}$ & $\begin{array}{l}\text { Sub-theme } \\
\text { (condensation) }\end{array}$ & $\begin{array}{l}\text { Theme } \\
\text { (abstraction) }\end{array}$ & $\begin{array}{l}\text { Overall } \\
\text { understanding } \\
\text { (in-depth } \\
\text { interpretation) }\end{array}$ \\
\hline $\begin{array}{l}\text { They are concerned } \\
\text { about how I am; they } \\
\text { help me with practical } \\
\text { things. }\end{array}$ & Caring professionals & \multirow{3}{*}{$\begin{array}{l}\text { Having an available } \\
\text { professional } \\
\text { companion }\end{array}$} & \multirow{5}{*}{$\begin{array}{l}\text { Seeking } \\
\text { security with a } \\
\text { professional } \\
\text { person you } \\
\text { have } \\
\text { confidence in, } \\
\text { and getting a } \\
\text { grip on your life } \\
\text { again }\end{array}$} \\
\hline $\begin{array}{l}\text { It is easy to get hold of } \\
\text { them; I just send a text } \\
\text { message, and they reply } \\
\text { quickly. }\end{array}$ & $\begin{array}{l}\text { Professionals who are } \\
\text { available }\end{array}$ & & \\
\hline $\begin{array}{l}\text { It is me who decides; I } \\
\text { choose what kind of help } \\
\text { I get. }\end{array}$ & Help on your own terms & & \\
\hline $\begin{array}{l}\text { I have the feeling of } \\
\text { being independent, of } \\
\text { feeling normal, that I } \\
\text { have come a long way. }\end{array}$ & Empowerment & \multirow[t]{2}{*}{$\begin{array}{l}\text { Taking the lead in } \\
\text { your life }\end{array}$} & \\
\hline $\begin{array}{l}\text { I have got a much better } \\
\text { life now. I have a } \\
\text { completely different } \\
\text { quality of life now that I } \\
\text { have my own home. I } \\
\text { hope that I can get a job } \\
\text { sometime. }\end{array}$ & $\begin{array}{l}\text { Recovery: Improved } \\
\text { quality of life and belief } \\
\text { in the future }\end{array}$ & & \\
\hline
\end{tabular}

Being available meant that the informants knew that the staff could be contacted whenever they were needed and that they responded quickly. It was important that the staff were available when the informants were having a particularly tough time, for example, on those days when they felt a strong urge to take drugs or felt very despondent. The informants also emphasized that the staff took the initiative to contact them:

She calls me when things are going to happen - yes, she seeks me out.

Availability also involved the staff providing help and support with everyday tasks, such as assembling furniture from lkea, driving to the shop, helping to remove the number plates from a car, and having a cup of coffee together at a café. It also meant a lot that the staff accompanied them to the doctor or dentist, to look at flats, or to help to sort out old debts:

They are available - that is worth its weight in gold. I get help to write applications, help to fill in forms from offices in Oslo. Mary goes there with me, so I don't have to go round Oslo on my own, and I avoid the temptations there. 
Many of the informants mentioned the importance of the help they got to sort out things with NAV, from a member of staff who had worked at NAV, instead of having to visit the NAV office. This meant that services regarding socialsecurity benefits and housing were available to them and were provided quickly and effectively in a way that they were not used to from NAV. Several of the informants used the expression 'closely followed up'. They found that the staff had more time and resources to follow them up than they were used to from before.

Several of the informants pointed out how positive they were towards the practice that the staff visited them at home, instead of meeting them at the office. This made help more available. One of them explained that being hostess for the member of staff at home made their relationship more equal, and it was less shameful to accept help. Also, having a member of staff who visited them at home helped them to establish routines for cleaning the house and keeping it tidy.

Having an available professional companion also gave them the experience of having a member of staff who cared about them. The staff were described as committed, liking their job, and having a job that suited them. One participant explained:

They are very dedicated in their work. I think they enjoy what they are doing. The members of staff are very human, which makes it so good. They care about you personally and are concerned about how you are doing.

At the same time, they pointed out that the help and support they received was 'sufficient', neither too much so that it was obtrusive, nor too little.

Staff members who cared were described as easy to talk to, open, attentive, understanding, and as people who one could talk with about anything. One informant told that the first conversation with a member of staff in the project lasted for four hours - which shows how time is a gift. Also, meeting a member of staff who had user-experience was described as a positive experience, because he understood what the problems were about:

If I tell him about things in my life, he knows what I mean. He doesn't need to sit there and ask and dig deeper: how does that work, how is this and that, because he knows what I am talking about.

The informants emphasized that they felt that the staff acknowledged and valued them: 'I see that she cares: I feel that I am not a case among other cases; I feel more valued.'

Other informants described how they received encouragement and acknowledgement from the staff. One of them put it this way:

You feel that they encourage you. I believe that they think it's good to see that you develop as well. Of course it helps; everyone likes to get a bit of praise. 


\title{
Taking the lead in your own life
}

This theme is about help on their own terms, empowerment, about improving one's life, and about belief in the future. The importance of getting help according to one's own terms was described as: 'I can give them the sack, but they cannot give me the sack, so I continue to get help, as long as I need it.' The following expressions were often repeated: 'It is me who decides'; 'Everything is according to what I order'; 'It is really your own choice; the staff live up to that'. These expressions can be interpreted to mean that the informants felt that they had control over the help they received, instead of being passive recipients. Having control also involves experiencing that the staff supported them, and it challenged them to be active and to take responsibility and initiative: 'It is a bit up to me, that I ask him if he has an hour to spare'. The expectation of taking responsibility could, for example, mean tidying up their home, or asking the informants what they could do themselves to improve their life situation:

They ask: 'What will you do to make your situation easier?' So they are clever, they don't stand behind you with a whip.

One informant told about the experience of being trusted, when he had the deposit paid into his bank account so that he himself could transfer the money to the landlord:

\begin{abstract}
With that deposit, I felt very independent, and felt as though I was normal, because the money was paid into my bank account. They trusted me, and since I had come so far, they said that they do not do this with everyone, but they chose to trust me. And just this gives me such a lot, to feel that NOW I really have come a long way. Then I could contact the owner alone and agree on a time when we could meet. We could meet at the bank and pay the money from my own bank account. It really was a good feeling that I have never experienced before.
\end{abstract}

This quotation shows and underscores the importance of being trusted and feeling valued after years of drug addiction, while at the same time being challenged. He responded to the trust by showing that he was able to take responsibility for the money. This also shows how strength and motivation can be mobilized when one is treated as an ordinary human being - as an equal. Being regarded as worthy seems to strengthen one's self-confidence and give a feeling of self-empowerment.

The transition from experiencing hopelessness to getting a grip on one's life was about beginning to believe in the future and making changes in one's life. The informants reported that a lack of accommodation made life difficult and that this led to poor health. They were neither able to think about the future nor do anything about their life situation. They pointed out that they wanted to live in a normal living environment, and not an area with a lot of drug abuse and crime:

You cannot manage to get out to work or school, or to finish such things. You have no chance to do this; you can't manage to get established. Because then you are on the slippery slope. And if you start taking drugs again, then it can get worse. 
When asked what participation in the project meant for the informants' lives, they used expressions such as: 'a better life', 'improved quality of life', 'recovery', and 'greater belief in the future'. In particular, they mentioned feeling greater peace and security, being more motivated to get a grip on their lives, and having more social contact.

Greater peace and security was closely associated with the knowledge that the staff were available. For many of them, they felt secure knowing that the staff had a key, and could get into their home if they had taken an overdose or were having a mental crisis. Several informants pointed out that life had become more peaceful with less intoxication after they had begun in the project:

When I think about it, I am actually happier now than I was two or three months ago. That is because I now know that I have people around me. For me, this feeling of security is really amazing, that they are there and that they do everything they can to help me.

For many of the informants, having got permanent accommodation seemed to increase their motivation to gain control of their lives:

Having got a flat has led to recovery. Because I feel that I have got new initiative and the desire to make an effort again, and to get on with tasks, and to begin to do something with myself again. My situation no longer seems so bleak.

Several of the informants told about dreams and hopes for a better life after they had come into the project. One of them dreamed about getting his schoolleaving certificate and beginning to study. Others dreamed about getting a job or buying their own flat.

Participation in the project, for many of them, also led to more social contact and activities related to work and school. One of them had begun physical training, others had begun to study subjects at school or to apply for jobs, and others believed that they had become more social. Another mentioned being reunited with his family as a very positive change: 'It has been an improvement in my life, for me, my mother, my family, and everyone.' From having had almost no contact with his family for several years, he now had regular contact with them. Another informant told that his life had changed completely after getting help with dental treatment. New teeth gave him a new quality of life because he could function socially again. He had hidden himself away for many years because he was ashamed about his appearance. Now he had the courage to contact people again and to smile and speak to them.

\section{Overall understanding}

Two quotations from informants express the overall understanding. One informant described his experience of participating in the project in the following way: 'It is like having a shoulder to lean on. This is necessary in order to come further in life.' Another participant put it this way: 'Earlier, life was just a struggle to survive, but now I have got my life back, I have begun to live.' The overall understanding is therefore about two interlocking themes: seeking security with a professional person you have confidence in and getting a grip on your life again. 


\section{Methodological considerations}

The descriptions of the informants' assessments and experiences of participation in the project indicate very positive results. This study represents a 'status report' after half a year's participation. The results can therefore be a 'honeymoon effect' partly because the project is new and different. Yet Skatvedt and Edland Gryt (2012) point out that people with addiction problems and mental-health problems have extensive experiences of being rejected by the health and social-care services. Therefore, many of them enter new projects with suspicion and scepticism. At the same time, they are very good at detecting whether they can rely on the helpers. Therefore, when the informants express such great satisfaction with the programme, there is reason to believe them. A new hope was kindled that improvement is possible, and that they could therefore begin to imagine a better life. It is possible that this new perspective has given them the courage to take the first steps towards managing their daily life independently.

A limitation of the study is that it is possible that the informants who took part in the study have a different understanding of the project than those who did not. We do not know how people with the most severe and active substance abuse experienced the project: those who had the greatest difficulties could not manage to be interviewed. Therefore there is a danger that the sample was biased. However, owing to this potential bias a sample of six persons of those with great difficulties were later interviewed about their experiences. The results from these interviews confirmed unanimously the findings from this study.

A strength of this study is that good contact, trust, and openness between the researcher and the participants were established during the interviews. The participants were strikingly unanimous in their experiences. All of them were encouraged by the staff before the interviews to share both their positive and their negative experiences. This was because this would provide useful information for improving the project. After the interviews, many of them apologized that they did not have anything critical to report.

\section{Discussion}

The aim of this study was to explore, describe, and interpret participants' experiences with participating in an HF project. The discussion is organized under the themes of a home of your own and person-centredness.

\section{A home of your own}

Acquiring a home of your own is reported both to be of vital importance for persons with mental-health and addiction problems (Andvig et al., 2013; Mezzina et al., 2006; Padgett, 2007) and to have a positive influence on recovery processes (Borg et al. 2005). A randomized controlled trial (Patterson et al., 2013) has found that participants in HF programmes reported significantly greater overall quality of life compared with clients in conventional treatment programmes. The differences were most notable concerning security and comfort and satisfaction with their living situation.

Our findings demonstrate how flexibility and availability of the professionals led the clients to experience a sense of security regarding their housing and their 
everyday life, which correspond with the HF principles. Tsemberis (2010) stresses that the clients should feel secure that the services are available for as long as they wish to receive them. This security establishes a basis for recovery (Watson, 2012). The findings show that homeless people are under chronic stress because of their efforts to survive with limited resources. Having the security that they will keep their housing and get support as long as they need it is connected with 'ontological security' (Padgett, 2007). Padgett (2007) suggests that 'housing can provide a fundamental building block for ontological security, thus lending support to a housing first approach' ( $p$. 1934). Ontological security is connected to the sense of continuity regarding life events. Life becomes coherent, and this stimulates the person to take responsibility for his or her own life.

The importance of receiving support to meet the challenges of everyday life is emphasized in several recovery studies (Drake \& Whitley, 2014; Slade, 2012; Topor et al., 2011; Williams \& Tufford, 2012). The findings support the importance of having an independent life and a feeling of belonging somewhere. Ordinary environments and activities emerge as the most common and recommended areas for mental-health recovery in contrast to mental-health or addiction service settings (Ness et al., 2014). Maintaining the routines of everyday life contributes to an orientation to the present. Being anchored in the present and the day-to-day efforts of being active give support to a greater chance of sobriety (Hipolito et al., 2011).

\section{Person-centredness}

The findings show that the HF project offered a different service from the one the informants were used to from NAV. Their experiences with NAV are in line with the findings of Erikson and Hummelvoll (2012) on users' descriptions of NAV as lacking personal and stable contact and of not being met with a helpful attitude from the providers. Such experiences of rejection can also be understood as stories about offence. Honneth (2008, p. 140) defines the concept of offence as types of 'contempt or lack of recognition'. The consequences can be loss of self-confidence, self-respect, and intrinsic value.

In the HF project, alternative characteristics of the providers as giving help and support with a focus on the individual, his or her preferences and skills, resources, and potential, instead of deficits and symptoms, are described as fundamental values in practising recovery-oriented services (Chen et al., 2013). These values can also be understood as person-centredness. Personcentredness has to do with establishing a relationship between the person and the professional based on values of mutual respect and understanding and of the individual's right to self-determination (cf. Barker \& Buchanan-Barker, 2009).

According to the findings, the descriptions of the availability of the providers may also reflect services that 'do more than' or 'do something different from' traditional services, something that Mezzina et al. (2006) and Denhov and Topor (2012) have noted as important factors in recovery. Staff who are warm and committed are also in line with the HF principles. It is essential that the staff are obliged to follow up the participants and to show in practice that they actually do this (Tsemberis, 2010). 
Adjusted and proper support in concrete situations means that the professional neither acts too early in fear of doing something wrong nor too late because of laxity or indifference, but acts when the time is ripe: proper closeness, proper distance, and suitable time spent. Thus, ideally the professional does not act 'en bloc' and summarily in relation to user groups, but meets the individual as a person and with a willingness to see what he or she basically is longing for and needing (Hummelvoll, 2006).

Findings concerning existential issues such as hope and optimism in this study are also reported in reviews of the recovery literature (Bonney \& Stickle, 2008; Leamy et al., 2011; Slade et al., 2012). Leamy et al. (2011) have identified hope and optimism about the future as a core component in personal recovery. It seems important that the participants experienced professionals who believed in them, shared their dreams and aspirations, and stimulated hope through encouragement, confidence, and positive expectations for the future (cf. Williams \& Tufford, 2012). A psychometric analysis of the core dimensions of recovery of 504 consumers (Gordon et al., 2014) has shown that hope and empowerment were connected. Hope was seen as a necessary precondition of empowerment and vice versa.

Our findings also emphasize empowerment. Being met with care and trust seems to strengthen personal responsibility and thus self-empowerment. The informants reported that they were encouraged to make their own choices and that they were supported in their decisions in a collaborative manner. This indicates a practice that mobilizes the person to participate and to interact with the environment. According to Slade et al. (2012), empowerment relates both to a sense of empowerment within the services, such as having control over the assistance and support that they are given, and having personal responsibility, including becoming an empowered member of society (Slade et al., 2012). Empowerment is understood as a critical dimension of recovery (Leamy et al., 2011; Slade et al., 2012). Empowerment entails that people gain power and control over their lives through access to meaningful choices and have the capacity to implement those choices. Our findings document the important role that making choices plays in the processes of empowerment. Participants are empowered when they make choices (and are given trust that they are able to do so) regarding where they live, housing, finances, employment, personal way of living, daily routines, and whom they wish to relate to. It is also important that they have the freedom to take risks and to fail.

However, we do not know how they experience being deeply involved in substance-abuse activities while at the same time participating in HF. Further research on this topic is important. Is having a certain functional capacity a prerequisite for the project to work?

\section{Implications for practice}

Having secure housing must be seen as part of an integrated support package: housing alone is not enough. The support package must ensure a broad range of community-oriented services that include education, employment, peer support, crisis support, and assistance in daily living. An integrated practice for this group should be centred on the person and focused on supporting the person to live a meaningful life. The professionals must emphasize seeing the person as a whole, believe in his or her potential, and 
be accessible. The services must be adjusted to the person's needs and be built on partnership, respect, the promotion of hope, and the facilitation of selfdetermination and choice. It is also important that the person has the right to receive support and adjustments in line with his or her choices, thus ensuring equal participation and citizenship.

\section{Conclusion}

This study shows that people with a double diagnosis can start the recovery process and achieve a better quality of life when they receive appropriate housing, support, and services according to their own choices and premises. The study also confirms the importance of the participants' active participation, management, and choice in planning and developing the support they receive and are offered. This is a prerequisite for receiving active help with rehabilitation. This means that the participants are partners in co-operation, who have a real influence on how the services are to be developed and how the follow-up is to be organized. This approach seems to be the key for establishing contact and developing a trusting relationship between the participants and the staff and the local community. The participants are no longer cases one can do something with, but persons who participate in a collaboration with their own lives as the main project. The results of this study show that if a person wishes and dares to change his or her life, then the decisive conditions are having one's own home and meeting staff who are trustworthy, who accept them, and who recognize their personal preferences and needs.

\section{References}

Andvig, E., Lyberg, A. Karlsson, B. \& Borg, M. (2013). Et anstendig liv. Erfaringer med å skape et hjem for mennesker med rus- og psykiske helseproblemer. (A decent life. Experiences with creating a home for persons with substanse abuse and mental health problems). Tidsskrift for psykisk helsearbeid, 10(2), 160-170.

Antony, W.A. (1993). Recovery from mental illness: The guiding vision of the mental health service system in the 1990s. Psychosocial Rehabilitation Journal, 16(4), 11-23.

Atherton, I. \& McNaughton Nicholls, C. (2008). 'Housing First' as a means of addressing multiple needs and homelessness, European Journal of Homelessness, 2, 289-303.

Barker, P. \& Buchanan-Barker, P. (2009). Getting personal: being human in mental health care. In: P. Barker (Ed.). Psychiatric and Mental Health Nursing. The Craft of Caring. London: Hodder Arnold.

Bonney, S., \& Stickley, T. (2008). Recovery and mental health: a review of the British literature. J Psychiatr Ment Health Nurs, 15(2), 140-153. doi: 10.1111/j.13652850.2007.01185.

Borg, M., Sells, D., Topor, A., Mezzina, R., Marin, I. \& Davidson, L. (2005). What makes a house a home: the role of material resources in recovery form severe mental illness. American Journal of Psychiatric Rehabilitation, 8(3), 243-256.

Busch-Geertsema, V. (2014). Housing First Europe. Results of a European Social Experimentation Project. European Journal of Homelessness, 8(1), 13-28. 
Chen, S-P., Krupa, T., Lysaght, R., McCay, E. \& Piat, M. (2013). The development of recovery competencies for in-patient mental health providers working with people with serious mental illness. Administration and Policy in Mental Health and Mental Health Services Research, 40(2), 96-116.

Denhov, A. \& Topor, A. (2012). The components of helping relationships with professionals in psychiatry: Users' perspective. International Journal of Social Psychiatry, 58(4), 417-424.

Drake, R.E. \& Whitley, R. (2014). Recovery and severe mental illness; description and analysis. La revue canadienne de psychiatrie, 59(5), 236-242.

Erikson, B.G \& Hummelvoll, J.K. (2012). To live as mentally disabled in the risk society. Journal of Psychiatric and Mental Health Nursing, 19(11), 594-602.

Gilmer, T.P., Stefancic, A., Ettner, S.L., Manning, W.G. \& Tsemberis, S. (2010). Effect of Full-Service Partnerships on Homelessness, Use and Costs of Mental Health Services, and Quality of Life Among Adults With Serious Mental Illness. Arch Gen Psychiatry, 67(6), 645-652.

Gordon, S.E., Ellis, P.M., Siegert, R.J. \& Walkey, F.H. (2014). Core dimensions of recovery: a psychometric analysis. Administration and Policy in Mental Health and Mental Health Services Research, 41(4), 535-542.

Hipolito, M.M., Carpenter-Song, E. \& Whitley, R. (2011). Meanings of recovery from the perspective of people with dual diagnosis. Journal of Dual Diagnosis, 7(3), 141149 .

Honneth, A. (2008). Kamp om anerkjennelse: Om de sosiale konfliktenes moralske grammatikk.(The struggle for recognition: the moral grammar of social conflicts). Oslo: Pax Forlag.

Hummelvoll, J.K. (2006). Verdiundersøkende samtaler i lokalsamfunnsbasert psykisk helsearbeid. (Dialogues on basic values in community mental health care) Tidsskrift for psykisk helsearbeid, 3(2), 116-129.

Kertesz, S.G., Crouch, K., Milby. J.B., Cusimano, R.E. \& Schumacher, J.E. (2009). Housing First for Homeless Persons with Active Addiction: Are we Overreaching? The Milbank Quarterly, 87(2), 495-534.

Kvale, S. \& Brinkman, S. (2011). Interview. Introduction til et håndverk. (Interview. Introduction to a craft). København: Hans Reizel.

Leamy, M., Bird, V., LeBoutillier, C., Williams, J. \& Slade, M. (2011). Conceptual framework for personal recovery in mental health: systematic review and narrative synthesis. The British Journal of Psychiatry, 199(6), 445-452.

Lindseth, A. \& Norberg, A. (2004). A phenomenological hermeneutical method for researching lived experience. Scandinavian Journal of Caring Sciences, 18(2), 145-153.

Mares, A.S. \& Rosenheck, R.A. (2010). Twelve month client outcomes and service use in a multi site project for chronical homeless adults. Journal of Behavioral Health Services \& Research, 37(2), 167-183.

Mezzina, R., Davidson, L., Borg, M., Marin, L., Topor, A. \& Sells, D. (2006). The social nature of recovery. Discussion and implications for practice. American Journal of Psychiatric rehabilitation, 9(1), 63-80.

National Registry of Evidence-Based Programs and Practices (2010, Nov 18). NREPP: Pathways' housing first program. Retrieved from http://nrepp.samhsa.gov/ViewIntervention.aspx?id=155 
Ness, O., Borg, M. \& Davidson, L. (2014). Facilitators and barriers in dual recovery: a literature review of first-person perspectives. Advances in Dual Diagnosis, 7(3), 107-117.

Nooe, R.M. \& Patterson, D.A. (2010) The ecology of homelessness. Journal of Psychiatric Behavior in the Social Environment, 20(2), 105-152.

Norwegian Board of Health Supervision (2000). Personer med samtidig alvorlig psykisk lidelse og omfattende rusmisbruk. (Persons with severe psychological illness and extensive drug abuse). IK-2727, Oslo.

Norwegian Directorate of Health (2012) Nasjonal Faglig Retningslinje for Utredning, Behandling og Oppfølging av Personer med Samtidige Lidelser. (National Guidelines for Assessment, Treatment and Follow up of People with Both Mental Health Problems and Addiction Problems). Oslo: Norwegian Directorate of Health.

Official Norwegian Reports (2011:15) Rom for alle. En sosial boligpolitikk for framtiden. (Room for everyone. A social housing policy for the future). Oslo: Ministry of Local Government and Modernisation.

Padgett, D.K. (2007). There's no place like (a) home: Ontological security among persons with serious mental illness in the United States. Social Science \& Medicine, 64(9), 1925-36.

Padgett, D.K., Gulcur, L. \& Tsemberis, S. (2006). Housing first services for people who are homeless with co-occurring serious mental illness and substance abuse. Research on Social Work Practice, 16(1), 74-83.

Patterson, M., Moniruzzaman, A., Palepu, A., Zabkiewicz, D., Frankish, C.J., Krausz, M. \& Somers, J. (2013). Housing First improves subjective quality of life among homeless adults with mental illness: 12 month findings from a randomized controlled trial in Vancouver, British Columbia. Social Psychiatry and Psychiatric Epidemiology, 48(8), 1245-1259. DOI 10.1007/s00127-013-0719-6

Pearson, C.L., Montgomery, A.E. \& Locke, G. (2009). Housing stability among homeless individuals with serious mental illness participating in housing first programs. Journal of Community Psychology, 37(3), 404-417.

Pleace, N. (2011). The Ambiguities, Limits and Risks of Housing First from a European Perspective. European Journal of Homelessness, 5(2), 113-127.

Ricoeur, P. (1976). Interpretation theory: Discourse and the surplus of meaning. Fort Worth: Texas Christian University Press.

Skatvedt, A. \& Edland-Gryt, M. (2012). Øyeblikksomsorg - et verktøy for bedring. Evaluering av 24SJU - et lavterskeltilbud til personer med dårlig psykisk helse og rusmiddelproblemer. (Emergency care - a tool for recovery. Evaluation of 24SEVEN - Iow threshold services for persons with poor mental health and drug related problems). Sirus rapport nr. 4. Oslo: Statens institutt for rusmiddelforskning.

Slade, M. (2012). Everyday solutions for everyday problems: how mental health systems can support recovery. Psychiatric Services, 63(7), 702-704.

Slade, M., Leamy, M., Bacon, F., Janosik, M., LeBoutillier, C., Williams, J. \& Bird, V. (2012). International differences in understanding recovery: a systematic review. Epidemiology and Psychiatric Sciences, 21(4), 353-364.

Snertingdal, M.I. (2014). Housing First $i$ Norge - en kartlegging. (Housing First in Norway - a mapping). Fafao-rapport 2014:52. 
Topor, A., Borg, M., Di Girolamo, S. \& Davidson, L. (2011). Not just an individual journey: social aspects of recovery. International Journal of Social Psychiatry, 57(1), 90-99.

Tsai, J., Bond, G.R., Salyers, M.P., Godfrey, J.L. \& Davis, K.E. (2010). Housing preferences and choices among adults with mental illness and substance use disorders: a qualitative study. Community Mental Health Journal, 46(4), 381388.

Tsemberis, S. (2010). Housing First: The Pathways Model to End Homelessness for People with Mental IIIness and Addiction. Center City, MN: Hazelden.

Tsemberis, S., Gulcur, L. \& Nakae, M. (2004). Housing First, Consumer Choice, and Harm Reduction for Homeless Individuals With a Dual Diagnosis. American Journal of Public Health, 94(4), 651-656.

Tsemberis, S., Kent, D. \& Respress, C. (2012). Housing Stability and Recovery Among Chronically Homeless Persons With Co-Occuring Disorders in Washington, DC. American Journal of Public Health, 102(1), 13-16.

Watson, D.P. (2012). From structural chaos to a model of consumer support: Understanding the roles of structure and agency in mental health recovery for the formerly homeless. Journal of Forensic Psychology Practice, 12(4), 325348. http://dx.doi.org/10.1080/15228932.2012.695656

White papers 30 (2011-2012). Se meg! En helhetlig rusmiddelpolitikk, alkoholnarkotika-doping.. (See me! An overall drug policy: alcohol-drug-doping). Oslo: Ministry of Health and Care Services.

Williams, C. \& Tufford, L. (2012). Professional competencies for promoting recovery in mental illness. Psychiatry, 75(2), 190- 201. 